\title{
High ammonium production from sediments in hypereutrophic shrimp ponds
}

\author{
Michele A. Burford ${ }^{1,3, *}$, Andrew R. Longmore ${ }^{2,3}$ \\ ${ }^{1}$ CSIRO Marine Research, PO Box 120, Cleveland, Queensland 4163, Australia \\ ${ }^{2}$ Marine and Freshwater Resources Institute, Queenscliff, Victoria 3225, Australia \\ ${ }^{3}$ Cooperative Research Centre for Aquaculture, Australia
}

\begin{abstract}
Intensive shrimp ponds are hypereutrophic ecosystems with high nutrient loading rates. The contribution of sediment nutrient fluxes to nutrient cycling in shrimp ponds was studied. Benthic processes were quantified using benthic chambers (clear and dark) on the sediment of intensive shrimp ponds at 3 farms. The ponds contained 2 distinct sediment zones: an outer zone of sand and rubble swept clean by the action of paddlewheels and other aerators (65 to $85 \%$ of the pond area), and an inner zone where settled particulate matter formed a sludge pile. The high nutrient loads, in the form of formulated feed, coupled with high sediment deposition resulted in an anoxic sediment in the pond center with a low respiratory quotient (oxygen:carbon dioxide ratio). The carbon dioxide effluxes were 2- to 4 -fold higher than oxygen consumption. The highest nutrient flux rates from the sediment were those of ammonium $\left(\mathrm{NH}_{4}^{+}\right)$, particularly in the inner sludge zone (up to $182 \mathrm{mmol} \mathrm{m} \mathrm{m}^{-2} \mathrm{~d}^{-1}$ ). Inferred denitrification efficiency was low $(<2 \%)$, particularly in the inner sludge zone. Denitrification rates, as measured by the acetylene block method, confirmed this. Denitrification may be limited by nitrate $\left(\mathrm{NO}_{3}{ }^{-}\right)$availability. It is unclear why $\mathrm{NO}_{3}{ }^{-}$concentrations were low, but nitrifiers either may have been inhibited by pond conditions or were unable to become established due to the routine water discharges to maintain adequate water quality. Fluxes of urea and $\mathrm{PO}_{4}{ }^{3-}$ were also low. This study shows that low rates of nitrogen loss from denitrification, relative to the high nitrogen inputs, results in high $\mathrm{NH}_{4}{ }^{+}$concentrations in the water column. The discharges of pond water mean that sediment processes in shrimp ponds ultimately affect the nitrogen loads discharged into the aquatic environment, exacerbating the potential for eutrophication caused by shrimp farming activities.
\end{abstract}

KEY WORDS: Benthic chambers $\cdot$ Nutrient fluxes $\cdot$ Shrimp $\cdot$ Ammonium $\cdot$ Aquaculture ponds Resale or republication not permitted without written consent of the publisher

\section{INTRODUCTION}

Nutrient cycling in shallow water ecosystems is critically influenced by the interactions between the sediment and the water. The microbial community plays a major role in the transformation of organic matter deposited on the sediment floor, which in turn provides a source of remineralized nutrients for plankton growth. The deposition of detrital loads, resulting from plankton and other organisms, increases in eutrophic waters (Jickels 1998). High nutrient loads may result in hy-

*E-mail: michele.burford@csiro.au poxia and higher rates of nutrient cycling, but may also alter the major pathways by which nutrients are recycled, e.g. by inhibition of nitrification and preferential release of ammonium $\left(\mathrm{NH}_{4}^{+}\right)$(Jørgensen 1996). Some sediments may be extremely efficient at removing an increased nitrogen $(\mathrm{N})$ load by denitrification, rather than returning it to the water column in forms available for algal growth (Seitzinger 1988, Berelson et al. 1998.)

Intensive shrimp aquaculture ponds are examples of hypereutrophic systems with high inputs of nutrients, particularly N, as formulated feed. Much of this feed is not retained by the cultured species but enters the pond system as particulate and dissolved nutrients (Briggs \& Funge-Smith 1994, Martin et al. 1998, Preston et al. 
2000). In order to maintain adequate water quality hypereutrophic water containing nutrients derived from feed is released into coastal waterways.

Shrimp farming is a rapidly expanding industry with an annual production of $860000 \mathrm{t}$ (Rosenberry 2000). The bulk of the production is in tropical and subtropical areas of the world, principally in developing countries for markets in the industrialized world. The unchecked growth of shrimp aquaculture in many of these countries has led to environmental degradation, including eutrophication of coastal and estuarine areas. The shrimp aquaculture industry is therefore under increasing pressure to reduce its effects on the natural environment (Naylor et al. 1998, 2000).

Despite the environmental concerns regarding intensive shrimp aquaculture, the role of the sediment in processing waste nutrients in shrimp ponds has received little attention. While there have been studies describing sediment characteristics and quantifying sediment nutrients, bacterial numbers and productivity (Moriarty 1986, Smith 1996, Burford et al. 1998), there is a paucity of data on microbial processing of waste nutrients and the resulting effect on water quality.

Most previous studies on the role of sediment in either remineralizing or assimilating waste nutrients have been below fish cages and ponds in temperate regions of the world. High porewater $\mathrm{NH}_{4}{ }^{+}$concentrations and $\mathrm{NH}_{4}{ }^{+}$fluxes have been measured in numerous studies (Hargreaves 1998, Karakassis et al. 1998, Christensen et al. 2000). In contrast, the efficiency of removal of the high input loads of $\mathrm{N}$ from aquaculture via denitrification was generally low, despite the variation in denitrification rates between and within studies (Kaspar et al. 1985, 1988, Hall et al. 1992, Christensen et al. 2000). It is not known how applicable these results are to tropical shrimp ponds where shrimp are continually bioturbating the sediment.

This study examined the effect of high nutrient loads on shrimp pond sediments to determine the dominant nutrient cycling pathways and, hence, the role of the sediment in ameliorating or exacerbating the effects of high nutrient loadings to coastal waterways.

\section{MATERIALS AND METHODS}

Experiments were conducted at 3 commercial shrimp farms: 2 in subtropical southeast Queensland, Australia (Farm 1 on a mangrove-lined tidal creek, $27^{\circ} 30^{\prime} \mathrm{S}, 153^{\circ} 20^{\prime} \mathrm{E}$, and Farm 2 on the mouth of a river, $27^{\circ} 45^{\prime} \mathrm{S}, 153^{\circ} 20^{\prime} \mathrm{E}$ ) and 1 on a mangrove-lined tidal creek in tropical northern Queensland, Australia (Farm 3, 18 $17^{\prime} \mathrm{S}, 146^{\circ} 2^{\prime} \mathrm{E}$ ). Each farm contained a number of earthen ponds, generally with the dimen- sions of $100 \mathrm{~m} \times 100 \mathrm{~m}$. Ponds were 1.4 to $1.6 \mathrm{~m}$ deep. The 2 farms in southeast Queensland were stocked with Penaeus monodon while at the northern farm, ponds were stocked with $P$. merguiensis. Animals were stocked at a density of 30 to $40 \mathrm{~m}^{-2}$ and fed high-N formulated feed. Ponds were aerated with a combination of paddlewheels and propeller-aspirators, the number and position of which varied from pond to pond. The aerators were positioned along the outer region of each pond to circulate water within the perimeter of the pond and to concentrate particulate matter in the water column into the pond center. The water velocity near the sediment surface varied from $<1 \mathrm{~cm} \mathrm{~s}^{-1}$ in the middle to $>10 \mathrm{~cm} \mathrm{~s}^{-1}$ at the edge.

Benthic chambers. Four chambers, 2 of clear plastic (perspex) and 2 of blackened perspex were used in the flux experiments. The chamber design is described by Nicholson et al. (1999). When each chamber was pushed into the sediment, about $6 \mathrm{l}$ of water was trapped over $0.07 \mathrm{~m}^{2}$ of sediment. At the top of each chamber was a sealed sampling tube, a capillary tube to allow ambient water to replace that removed during sampling and a dissolved oxygen $\left(\mathrm{O}_{2}\right)$ probe. A fifth $\mathrm{O}_{2}$ probe was placed near the chambers to measure the ambient dissolved $\mathrm{O}_{2}$ concentration. An underwater data logger was programmed to pulse and read the $\mathrm{O}_{2}$ probes every $10 \mathrm{~min}$. Each chamber had a magnetically coupled stirrer with a stirring rate set to simulate a bottom current of $5 \mathrm{~cm} \mathrm{~s}^{-1}$.

At each farm, benthic chambers were deployed in 2 ponds, each of which had a crop that had been established for about 4 mo and had a high biomass of shrimp (Farm 1 had $5600 \mathrm{~kg} \mathrm{ha}^{-1}$, Farm 2 had $4300 \mathrm{~kg} \mathrm{ha}^{-1}$, and Farm 3 had $5700 \mathrm{~kg} \mathrm{ha}^{-1}$ ). There were 3 incubation sites, each with 4 chambers, in each pond: 1 in the outer region of the pond where water velocities were highest; 1 in the center of the pond where sedimented particulate matter (i.e. sludge) accumulated to the greatest degree; and 1 intermediate between the center and the edge where the sludge was a few centimeters deep. The precise volume of each chamber was determined by injection of cesium chloride into the chamber, then collection of a subsample of water from the chamber 5 min later. Samples for nutrients and alkalinity analysis were taken by a SCUBA diver from each chamber at 0, 0.5, 1, 2 and $3 \mathrm{~h}$.

Water samples were filtered under low pressure through glass fiber (GF/F, Whatman, Clifton, NJ) and $0.45 \mu \mathrm{m}$ cellulose acetate filters (Sartorius Edgewood, NY) for nutrient analyses and alkalinity titrations. Filtrates were stored on ice (alkalinity, Dickson \& Goyet 1996) or frozen (nutrients) until analyzed. An unfiltered subsample was also collected for $\mathrm{pH}$ determinations and stored on ice until measured within $6 \mathrm{~h}$ of collection. 
Sediment characteristics. The area and depth contour of the sedimented particulate matter (i.e. inner sludge zone), in each pond was measured by walking calibrated transects across each pond and measuring the depth of the sludge each $2 \mathrm{~m}$. In addition, sediment cores (50 mm deep, $24 \mathrm{~mm}$ diameter) were taken from 9 sites in the inner sludge region and from 9 sites in the outer region of each pond while the benthic chambers were deployed. In the laboratory, the cores from all sites in each region were pooled and mixed thoroughly. A subsample was taken for total Kjeldahl $\mathrm{N}$ and total organic $\mathrm{C}$ analyses. Samples were freeze-dried, sieved and digested, and total Kjeldahl $\mathrm{N}$ was analyzed using an autoanalyzer (Technicon 1977). For organic carbon (C), the sample was treated with acid/ iron chloride to liberate inorganic $\mathrm{C}$ and the resultant mixture was dried. The sample was then pyrolysed in a WR12 induction furnace (LECO, Mönchengladbach, Germany) in the presence of $\mathrm{O}_{2}$ to produce carbon dioxide $\left(\mathrm{CO}_{2}\right) \cdot \mathrm{CO}_{2}$ is detected by a thermal conductivity detector.

To measure porewater nutrients, sediment subsamples were centrifuged at $8000 \mathrm{rpm}$ for $5 \mathrm{~min}$. The porewater was decanted, filtered through a $0.45 \mu \mathrm{m}$ cellulose acetate filter (Sartorius) and frozen before being analyzed for $\mathrm{NH}_{4}{ }^{+}$and nitrite $\left(\mathrm{NO}_{2}{ }^{-}\right)+$nitrate $\left(\mathrm{NO}_{3}{ }^{-}\right)$ content (Parsons et al. 1984). Subsets of sediment were also weighed and total extractable $\mathrm{NH}_{4}{ }^{+}$was determined on $2 \mathrm{M}$ potassium chloride (KCl) extracts (Uddy \& Dennison 1997). The dry wt:wet wt ratio was determined by weighing subsamples before and after drying at $105^{\circ} \mathrm{C}$ for $24 \mathrm{~h}$.

Sample analyses. Inorganic nutrients $\left(\mathrm{NH}_{4}{ }^{+}, \mathrm{NO}_{2}^{-}\right.$, $\mathrm{NO}_{3}{ }^{-}$and phosphate $\left[\mathrm{PO}_{4}{ }^{3-}\right]$ ) were measured by a modification of standard segmented-flow auto-analysis methods. Urea was analyzed by the diacetyl monoxime method (Rahmatullah \& Boyde 1980). The $\mathrm{pH}$ of an unfiltered subsample of water was measured at $25^{\circ} \mathrm{C}$ with a $\mathrm{pH}$ electrode. Alkalinity was determined by a Gran titration at $25^{\circ} \mathrm{C}$. To estimate the relative importance of oxic and suboxic pathways, titration alkalinity was corrected for non-carbonate contributions (Berelson et al. 1998). Total $\mathrm{CO}_{2}$ concentrations were calculated from the $\mathrm{pH}$ and alkalinity values. Cesium concentrations were measured by direct sample aspiration and atomic emission spectroscopy.

Nutrient, $\mathrm{O}_{2}$ and $\mathrm{CO}_{2}$ fluxes were estimated by the linear regression of concentration changes with time, with correction of chamber sample concentration for dilution by ambient water drawn in during sampling. The inferred denitrification efficiency was calculated from the ratio of measured DIN fluxes versus expected DIN fluxes, which were based on the measured C:N ratios in the sediment and the $\mathrm{CO}_{2}$ fluxes (Berelson et al. 1998).
Denitrification/ $\mathbf{N}$ fixation. Sediment cores were also taken in 1 pond at Farm 1 for denitrification and Nfixation measurements using acetylene block/reduction techniques. Cores were taken from the outer and the inner sludge zone (12 in each zone). The cores from each region in the pond were pooled ( $50 \mathrm{~mm}$ deep) and mixed before $15 \mathrm{ml}$ subsamples were taken and placed in $6 \times 125 \mathrm{ml}$ Erlenmeyer flasks. Filtered water $(15 \mathrm{ml})$ from the same pond was added to each flask. Flasks were sealed and $\mathrm{N}_{2}$ gas was added to the airspace for 2 min to remove $\mathrm{O}_{2}$.

Acetylene gas $(15 \mathrm{ml})$ was then injected into the flasks. There were 2 treatments of either 0 and $50 \mu \mathrm{M}$ potassium nitrate $\left(\mathrm{KNO}_{3}\right)$ addition, with 3 replicates of each. The $\mathrm{KNO}_{3}$ was added immediately after the acetylene gas. At the start of the experiment and every following 1 to $2 \mathrm{~h}$ up to $8 \mathrm{~h}, 100 \mu \mathrm{l}$ gas subsamples were taken from each flask and injected into 2 gas chromatograms, one with an electron capture detector for nitrous oxide measurements and the other with a flame ionization detector for ethylene measurements. Ethylene and nitrous oxide standards were also regularly injected.

When $\mathrm{KNO}_{3}$ was not added, there was no nitrous oxide production. Therefore, only data generated from samples with $\mathrm{KNO}_{3}$ addition were used.

Quantification of dissimilatory $\mathbf{N}$ pathway. At Farm 2, the conversion of $\mathrm{NO}_{3}{ }^{-}$to $\mathrm{NH}_{4}{ }^{+}$by sediment processes was also quantified. A solution of ${ }^{15} \mathrm{~N}-\mathrm{KNO}_{3}$ $(24 \mu \mathrm{M})$ was added to 2 benthic chambers in the center of 1 pond. At $0,0.5,1,2$ and $3 \mathrm{~h}$, samples were taken and filtered through $0.45 \mu \mathrm{m}$ cellulose acetate filters and then frozen. Samples were distilled, and ${ }^{15} \mathrm{~N}-\mathrm{NH}_{4}{ }^{+}$ was collected and analyzed by mass spectroscopy .

\section{RESULTS}

This study of shrimp ponds late in the growth season showed that there were 2 distinct sediment zones: an inner sludge zone representing 15 to $35 \%$ of the pond area; and the outer zone, which was swept by the action of aerators (Table 1). Total Kjeldahl $\mathrm{N}$ and organic $\mathrm{C}$ were all about 3 times higher in the inner than in the outer zone of the ponds. Porewater $\mathrm{NH}_{4}{ }^{+}$ was 7 times higher in the inner zone than in the outer zone, and extractable $\mathrm{NH}_{4}{ }^{+}$was 20 times higher. The concentrations of $\mathrm{NO}_{2}{ }^{-}+\mathrm{NO}_{3}{ }^{-}$in the porewater were low in comparison with $\mathrm{NH}_{4}{ }^{+}$concentrations, and did not differ between the inner and outer zone.

At the time of the benthic chamber incubations, the maximum daily water temperatures were similar at Farms 1 and 2 , and about $5^{\circ} \mathrm{C}$ cooler at Farm 3 (Table 2). Salinity was close to that of seawater at Farm 1 and considerably lower at Farms 2 and 3. The $\mathrm{NH}_{4}{ }^{+}$ concentrations in the water were highly variable 
Table 1. Mean sediment nutrient concentrations of pooled samples from the inner sludge and outer zones of 2 ponds at each of 3 shrimp farms. TKN: total Kjeldahl nitrogen; nd: not determined; OC: organic carbon

\begin{tabular}{|c|c|c|c|c|c|c|}
\hline & \multicolumn{2}{|c|}{ Farm 1} & \multicolumn{2}{|c|}{ Farm 2} & \multicolumn{2}{|c|}{ Farm 3} \\
\hline & Sludge zone & Outer zone & Sludge zone & Outer zone & Sludge zone & Outer zone \\
\hline $\mathrm{KCl}$-extractable $\mathrm{NH}_{4}{ }^{+}\left(\mathrm{mmol} \mathrm{m}^{-2}\right)$ & 240 & 30 & 320 & 20 & 880 & 20 \\
\hline TKN $\left(\mathrm{mmol} \mathrm{m}^{-2}\right)$ & 8100 & 1730 & 7860 & 2150 & 5090 & 2480 \\
\hline $\mathrm{OC}\left(\mathrm{mmol} \mathrm{m}{ }^{-2}\right)$ & nd & nd & 40100 & 20000 & 35100 & 27000 \\
\hline Porewater $\quad \mathrm{NH}_{4}^{+}(\mu \mathrm{M})$ & 8950 & 1010 & 4560 & 930 & 4220 & 560 \\
\hline $\mathrm{NO}_{3}^{-}(\mu \mathrm{M})$ & 1.9 & 2.0 & 1.4 & 1.4 & 1.0 & 1.2 \\
\hline Pond area $(\%)$ & 15 & 85 & 35 & 65 & 35 & 65 \\
\hline
\end{tabular}

Table 2. Water quality at farms during benthic chamber experiments. Temp.: maximum temperature

\begin{tabular}{|c|c|c|c|c|c|c|c|c|}
\hline & $\begin{array}{c}\text { Temp. } \\
\left({ }^{\circ} \mathrm{C}\right)\end{array}$ & Salinity & $\mathrm{pH}$ & $\begin{array}{l}\mathrm{NH}_{4}^{+} \\
(\mu \mathrm{M})\end{array}$ & $\begin{array}{l}\mathrm{NO}_{2}^{-} \\
(\mu \mathrm{M})\end{array}$ & $\begin{array}{l}\mathrm{NO}_{3}^{-} \\
(\mu \mathrm{M})\end{array}$ & $\begin{array}{l}\text { Urea } \\
(\mu \mathrm{M})\end{array}$ & $\begin{array}{c}\mathrm{PO}_{4}{ }^{3-} \\
(\mu \mathrm{M})\end{array}$ \\
\hline \multicolumn{9}{|l|}{ Farm 1} \\
\hline Pond 1 & 30.8 & 32.7 & 7.97 & 55.73 & 0.73 & 0.32 & 7.83 & 0.21 \\
\hline Pond 2 & 29.4 & 31.8 & 8.19 & 1.95 & 0.06 & 0.12 & 0.14 & 0.17 \\
\hline \multicolumn{9}{|l|}{ Farm 2} \\
\hline Pond 1 & 31.2 & 24.0 & 7.73 & 91.22 & 17.16 & 3.15 & 12.89 & 0.23 \\
\hline Pond 2 & 31.3 & 23.5 & 7.80 & 85.89 & 15.74 & 9.16 & 18.89 & 0.12 \\
\hline \multicolumn{9}{|l|}{ Farm 3} \\
\hline Pond 1 & 26.0 & 23.3 & 7.65 & 85.64 & 2.14 & 3.49 & 24.96 & 0.35 \\
\hline Pond 2 & 24.5 & 22.3 & 8.12 & 85.27 & 2.71 & 3.48 & 16.82 & 0.20 \\
\hline
\end{tabular}

between ponds, ranging from 1.95 to $91.22 \mu \mathrm{M}$, and generally higher than $\mathrm{NO}_{2}{ }^{-}, \mathrm{NO}_{3}{ }^{-}$, urea and $\mathrm{PO}_{4}{ }^{3-}$ concentrations. The DIN and urea concentrations were substantially lower at Pond 2, Farm 1.

There were no differences in flux rates of reactants and products in dark and light benthic chambers. Therefore, data from all 4 chambers at each site within a pond were averaged. Incubation times were kept short (i.e. $3 \mathrm{~h}$ ) to prevent $\mathrm{O}_{2}$ depletion and ensure that

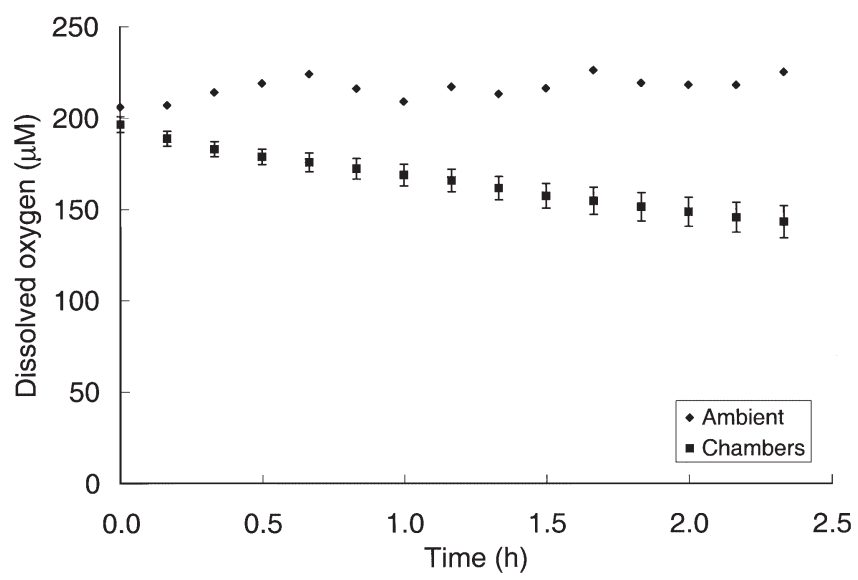

Fig. 1. An example of the changes in dissolved oxygen concentration $(\mu \mathrm{M})$ in benthic chambers (Chambers) and ambient concentrations (Ambient) in the water column of a shrimp pond during a $2.5 \mathrm{~h}$ incubation flux rates were linear (Fig. 1). Where $\mathrm{O}_{2}$ fluxes were non-linear with time, or where $\mathrm{O}_{2}$ concentrations within the chambers declined to less than $50 \%$ of ambient, only samples from the initial linear portion of the incubation were used to estimate fluxes.

The nutrient with the highest rate of efflux from the sediment irrespective of the pond or farm was $\mathrm{NH}_{4}{ }^{+}$ with rates as high as $182 \mathrm{mmol} \mathrm{m} \mathrm{m}^{-2} \mathrm{~d}^{-1}$ in the inner sludge zone (Table 3). Fluxes of $\mathrm{NH}_{4}{ }^{+}$increased linearly with increasing depth of settled sludge $\left(R^{2}=0.74\right.$, $\mathrm{p}<0.01$, Fig. 2a). The flux rates of $\mathrm{NO}_{3}{ }^{-}+\mathrm{NO}_{2}{ }^{-}$, urea and $\mathrm{PO}_{4}{ }^{3-}$ were all considerably lower (Table 3 ). In the case of urea and $\mathrm{PO}_{4}{ }^{3-}$, there was generally a net efflux, while for $\mathrm{NO}_{3}{ }^{-}+\mathrm{NO}_{2}{ }^{-}$there was mostly a net influx. There were no obvious differences in the flux rates in Pond 2, Farm 1 despite the lower DIN concentrations in the water column.

The rate of $\mathrm{CO}_{2}$ efflux from the sediment also increased with increasing sludge depth although the correlation was not statistically significant $\left(\mathrm{R}^{2}=0.41\right.$, $\mathrm{p}>0.05$, Fig. 2b). $\mathrm{O}_{2}$ consumption in the sediment did not increase with sludge depth $\left(\mathrm{R}^{2}=0.01\right.$, Fig. 2c). $\mathrm{CO}_{2}$ effluxes were generally 2- to 4 -fold higher than $\mathrm{O}_{2}$ consumption, particularly near the pond center, resulting in a low respiratory quotient $\left(\mathrm{O}_{2}: \mathrm{CO}_{2}\right)$ (Fig. 3).

The mean potential denitrification in the sediment of the shrimp pond at Farm 1, as measured using the acetylene block method, was lower in the inner sludge zone (Table 4). The reverse was true of $\mathrm{N}$ fixation in 
Table 3. Mean \pm SE flux rates of $\mathrm{NH}_{4}{ }^{+}, \mathrm{NO}_{3}{ }^{-}+\mathrm{NO}_{2}{ }^{-}$, urea and $\mathrm{PO}_{4}{ }^{3-}$ in ponds at 3 shrimp farms. Positive values indicate flux out of sediment; negative values indicate flux into sediment

\begin{tabular}{|lcrrr|}
\hline Site & $\begin{array}{c}\mathrm{NH}_{4}{ }^{+} \\
\left(\mathrm{mmol} \mathrm{m}^{-2} \mathrm{~d}^{-1}\right)\end{array}$ & $\begin{array}{c}\mathrm{NO}_{3}{ }^{-}+\mathrm{NO}_{2}{ }^{-} \\
\left(\mathrm{mmol} \mathrm{m}^{-2} \mathrm{~d}^{-1}\right)\end{array}$ & $\begin{array}{c}\text { Urea } \\
\left(\mathrm{mmol} \mathrm{m}^{-2} \mathrm{~d}^{-1}\right)\end{array}$ & $\begin{array}{c}\mathrm{PO}_{4}{ }^{3-} \\
\left(\mathrm{mmol} \mathrm{m}^{-2} \mathrm{~d}^{-1}\right)\end{array}$ \\
\hline Farm 1 & & & & \\
Pond 1 & $45.80 \pm 7.95$ & $-0.01 \pm 0.01$ & $0.76 \pm 0.42$ & $0.56 \pm 0.14$ \\
Pond 2 & $19.84 \pm 6.07$ & $0.01 \pm 0.02$ & $0.30 \pm 0.19$ & $0.13 \pm 0.17$ \\
Farm 2 & & & & \\
Pond 1 & $24.62 \pm 3.53$ & $-1.59 \pm 0.31$ & $0.01 \pm 0.45$ & $0.01 \pm 0.03$ \\
Pond 2 & $38.48 \pm 6.90$ & $-2.78 \pm 0.93$ & $2.33 \pm 0.48$ & $0.58 \pm 0.14$ \\
Farm 3 & & & & \\
Pond 1 & $26.51 \pm 3.83$ & $0.33 \pm 0.05$ & $-0.47 \pm 0.22$ & $0.47 \pm 0.11$ \\
Pond 2 & $11.28 \pm 1.54$ & $-0.53 \pm-0.09$ & $0.38 \pm 0.75$ & $-0.01 \pm 0.01$ \\
\hline
\end{tabular}

the sediment, with higher mean rates in the sludge zone. Rates of conversion of $\mathrm{NO}_{3}{ }^{-}$to $\mathrm{NH}_{4}{ }^{+}$(dissimilatory $\mathrm{N}$ pathway) in the sludge zone were low.

\section{DISCUSSION}

The shrimp pond sediments in this study were highly anoxic (as measured by the low respiratory quotient) and were characterized by high $\mathrm{NH}_{4}{ }^{+}$ effluxes, particularly in the pond center. Previous studies have shown that detritus and fine inorganic soil accumulate in the pond center, due to the
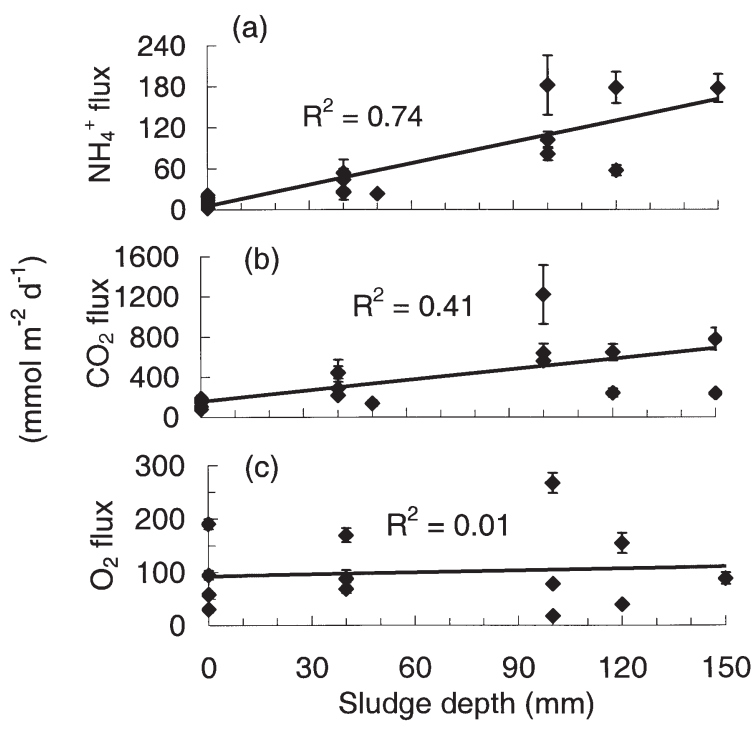

Fig. 2. Mean \pm SE of benthic flux measurements $\left(\mathrm{mmol} \mathrm{m}^{-2}\right.$ $\mathrm{d}^{-1}$ ) with increasing sludge depth $(\mathrm{mm})$ at 3 sites in 2 ponds at each of 3 shrimp farms. (a) Ammonium $\left(\mathrm{NH}_{4}{ }^{+}\right)$efflux, (b) carbon dioxide $\left(\mathrm{CO}_{2}\right)$ efflux, (c) $\mathrm{O}_{2}$ influx

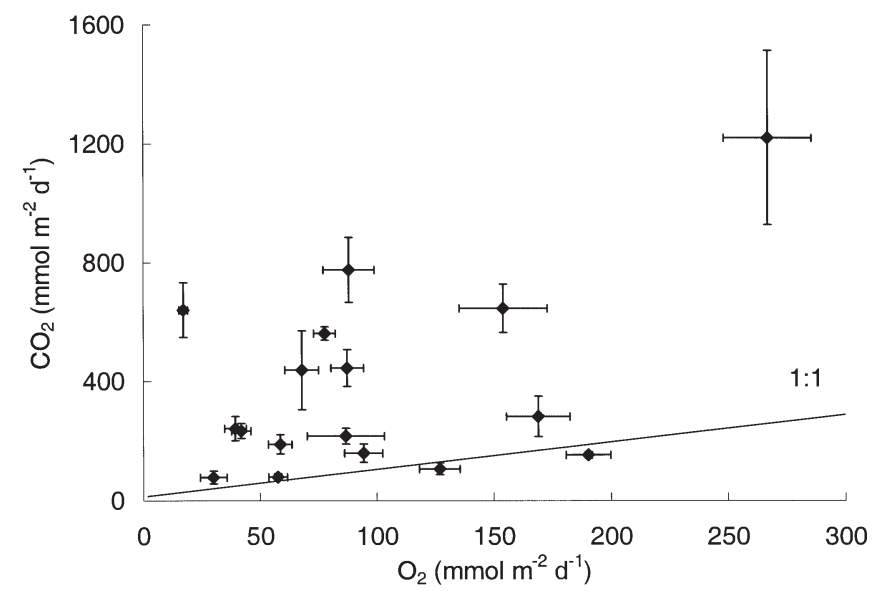

Fig. 3. $\mathrm{O}_{2}$ versus $\mathrm{CO}_{2}$ benthic fluxes $\left(\mathrm{mmol} \mathrm{m}^{-2} \mathrm{~d}^{-1}\right)$ from 3 sites in 2 ponds at each of 3 farms. The line represents a ratio of $1: 1$ action of aeration devices, creating a thick, black sludge. Most of this sludge (Smith 1996, Burford et al. 1998) is inorganic material scoured from the pond walls and floor (Peterson 1999).

$\mathrm{O}_{2}$ fluxes into the sediment were comparable with those measured in fish ponds, in shellfish farms and below fish cages (Blackburn et al. 1988, Boucher \& Boucher-Rodoni 1988, Mazouni et al. 1996, Riise \& Roos 1997, Christensen et al. 2000). $\mathrm{CO}_{2}$ fluxes were 2- to 4 -fold higher than $\mathrm{O}_{2}$ fluxes indicating that most of the C (50 to $80 \%$ ) was oxidized by subaerobic pathways. Possible pathways may include $\mathrm{NO}_{3}^{-}$, iron/manganese or sulfate reduction or methanogenesis (Santschi et al. 1990). From both the failure to observe significant $\mathrm{NO}_{3}{ }^{-}$fluxes into the sediment and the relatively low estimates of denitrification rate (see below), it can be concluded that $\mathrm{NO}_{3}{ }^{-}$reduction was a minor pathway in these ponds. Iron and manganese fluxes were not measured but these compounds are unlikely to be present in significant concentrations. In organic-rich coastal sediments, most anaerobic mineralization is by sulfate reduction (Jørgensen 1996), and this is also the most likely pathway in shrimp ponds.

The similarity in the $\mathrm{O}_{2}$ fluxes between the light and dark chambers suggests that photosynthesis by benthic microalgae was minimal. This is presumably due to the high turbidity and, hence, low light availability ( $2 \%$ of surface irradiance) on the sediment floor (Burford 1997). Additionally, in the inner sludge zone, continual sediment deposition in the inner sludge zone and resuspension by aerators in the outer zone would reduce the establishment of benthic microalgae.

\section{$\mathrm{NH}_{4}{ }^{+}$fluxes}

The sediments at all 3 farms were characterized by high concentrations of porewater and $\mathrm{KCl}$-extractable 
Table 4. Mean \pm SE rates of denitrification, $\mathrm{N}$ fixation and the dissimilatory N pathway at a shrimp farm (Farm 1). Acetylene block method had $50 \mu \mathrm{M}$ nitrate- $\mathrm{N}$ addition

\begin{tabular}{|llcr|}
\hline N process & Method & Inner sludge zone & Outer zone \\
\hline Denitrification & Acetylene block method & $0.179 \pm 0.005$ & $0.593 \pm 0.111$ \\
N Fixation & Acetylene reduction & $0.186 \pm 0.028$ & $0.047 \pm 0.009$ \\
Dissimilatory N pathway $\left(\mathrm{mmol} \mathrm{m}^{-2} \mathrm{~d}^{-1}\right)$ & ${ }^{15} \mathrm{NO}_{3}$ addition & 0.094 & \\
\hline
\end{tabular}

Table 5. Comparison of $\mathrm{NH}_{4}{ }^{+}$fluxes in shrimp ponds with other estuarine and coastal sites

\begin{tabular}{|lll|}
\hline $\mathrm{NH}_{4}{ }^{+}$flux $\left(\mathrm{mmol} \mathrm{m}^{-2} \mathrm{~d}^{-1}\right)$ & Site & Source \\
\hline Sub/Tropical fish/crustacean ponds & & \\
28 & Shrimp pond - whole pond & sludge zone \\
68 & \multicolumn{1}{c}{ Parine fish pond } & Present study \\
27 & Polyculture fish pond & Blackburn et al. (1988) \\
13 & & Riise \& Roos (1997) \\
Temperate shellfish/fish cage sites & Mussel farms & \\
29 & Trout cage farm & Kasper et al. (1985) \\
12 & Oyster ponds & Christensen et al. (2000) \\
11 & Striped bass cages & Sornin et al. (1990) \\
8.6 & Oyster beds & J. Cornwell (pers. comm.) \\
5.9 & Trout cage farm & Boucher \& Boucher-Rodoni (1988) \\
0.82 & Shellfish farming lagoon & Hall et al. (1992) \\
0.6 & & Mazouni et al. (1996) \\
\hline
\end{tabular}

$\mathrm{NH}_{4}{ }^{+}$, particularly in the inner sludge zone, and high fluxes of $\mathrm{NH}_{4}{ }^{+}$from the sediment, which increased with increasing sludge depth. These flux rates were higher than in other aquaculture ponds, below cages and in shellfish beds (Table 5). The whole-pond integrated $\mathrm{NH}_{4}{ }^{+}$fluxes were comparable with those in other aquaculture systems with high $\mathrm{N}$ loads, ie., the sediment of fish ponds and a mussel farm, and higher than those in the sediment below fish cages. Our experiment was conducted late in the growth season when sludge and feed loads were highest. Earlier in the growth season, $\mathrm{NH}_{4}{ }^{+}$flux rates were likely to be much lower.

The high $\mathrm{NH}_{4}{ }^{+}$production in the sediment was presumably the result of the high waste $\mathrm{N}$ loads resulting from shrimp feeding. Previous studies have shown that most of the feed added to ponds is not retained by shrimp but enters the pond system (Briggs \& FungeSmith 1994, Preston et al. 2000). Much of the resultant uneaten feed, feces and other detritus from water column processes must inevitably settle on the sediment floor where it is subject to remineralization processes. Feed wastage is higher from shrimp farming than from other intensively reared aquaculture species (Phillips et al. 1993). This may explain the higher remineralization rates in the inner sludge zone of shrimp ponds. Another important difference between shrimp and fish aquaculture is that shrimp are benthic and bioturbate the sediment, which is likely to affect $\mathrm{O}_{2}$ levels and nutrient processes in the sediment.
The $\mathrm{NH}_{4}{ }^{+}$flux rate $\left(28 \mathrm{mmol} \mathrm{m}^{-2} \mathrm{~d}^{-1}\right)$ of the sediment in the ponds in this study was $68 \%$ of the total $\mathrm{NH}_{4}{ }^{+}$regeneration rate in intensive shrimp ponds (Burford \& Glibert 1999). The $\mathrm{NH}_{4}{ }^{+}$produced from these regeneration processes is rapidly assimilated by the phytoplankton in these systems. In contrast to benthic algae, phytoplankton production is high (Burford 1997). This is due to the action of aerators, which ensures that cells are exposed to sufficient light to support growth. The presence of a high phytoplankton biomass results in diel fluctuations in $\mathrm{O}_{2}$ concentrations and pH (Burford \& Glibert 1999); however, the action of the aerators prevents anoxia $\left(\left[\mathrm{O}_{2}\right]\right.$ $<2 \mathrm{mg} \mathrm{l}^{-1}$ ) from developing in the water column at night. Nutrient fluxes were not measured at night, but the lower temperatures and $\mathrm{O}_{2}$ concentrations may affect flux rates.

\section{Denitrification efficiency}

Flux rates of DIN from the sediment were compared with expected flux rates calculated from measured $\mathrm{CO}_{2}$ fluxes and the measured $\mathrm{C}: \mathrm{N}$ ratio of the sediment (expected DIN flux) in the inner and outer regions of each pond. The difference between the 2 rates (i.e. when the observed DIN flux was lower than the expected DIN flux) was assumed to be due to denitrification. At many of the sites within the ponds, the calculated and measured DIN fluxes were similar, indicative of low rates of denitrification (the line in Fig. 4 shows a ratio of 1:1). In 


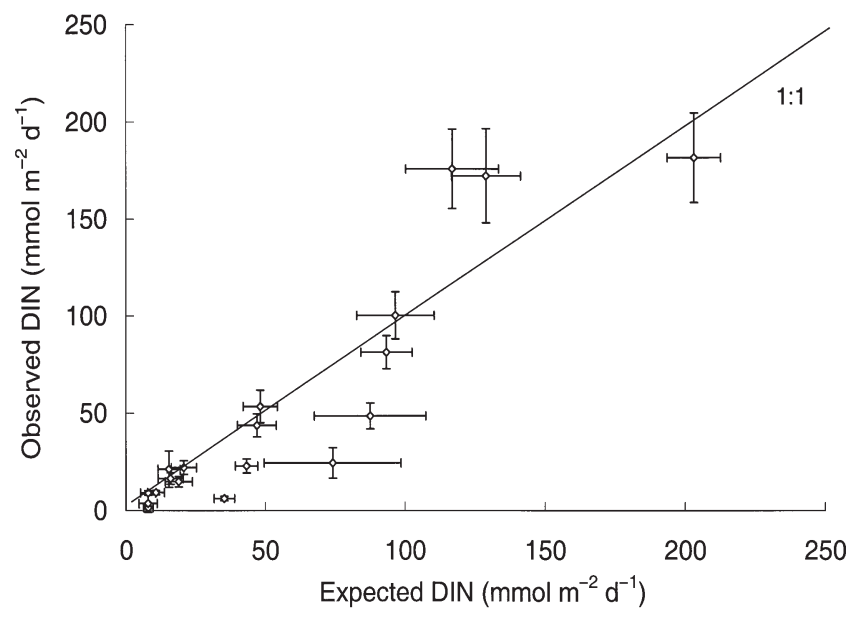

Fig. 4. Expected versus observed DIN flux rates $\left(\mathrm{mmol} \mathrm{m}^{-2} \mathrm{~d}^{-1}\right)$ in the sediment at 3 sites in 2 ponds at each of 3 farms. Expected fluxes were calculated from $\mathrm{CO}_{2}$ fluxes and measured carbon:nitrogen ratios in the sediment. The line represents a ratio of $1: 1$

comparison, denitrification values based on the acetylene block method $\left(0.47 \mathrm{mmol} \mathrm{m}^{-2} \mathrm{~d}^{-1}\right)$, were lower than those calculated from the benthic flux data $(2.05 \mathrm{mmol}$ $\mathrm{m}^{-2} \mathrm{~d}^{-1}$ ). A previous study has shown that the acetylene block method may lead to an underestimation of denitrification compared with other methods, consistent with our results.

Seitzinger (1998) compared denitrification rates and $\mathrm{N}$ input loads in a number of marine systems, and showed that denitrification increases linearly with increasing $\mathrm{N}$ input up to $12 \mathrm{mmol} \mathrm{m}^{-2} \mathrm{~d}^{-1}$. The $\mathrm{N}$ inputs in the present study were much higher $\left(75 \mathrm{mmol} \mathrm{m}^{-2}\right.$ $\mathrm{d}^{-1}$ ) and in an organic form, and denitrification efficiency was lower, as indicated by both the acetylene block and benthic chamber methods (Fig. 5). The results of this study confirm findings that high organic $\mathrm{N}$ and $C$ loadings decrease denitrification efficiency (Sloth et al. 1995, Heggie et al. 1999). This was despite the fact that a range of techniques (acetylene block, $\mathrm{N}_{2}$ production, benthic chamber measures, $\mathrm{NO}_{3}{ }^{-}$anomalies) was used across the studies. The data suggest that denitrification rates decline at $\mathrm{N}$ inputs above $20 \mathrm{mmol} \mathrm{m}^{-2} \mathrm{~d}^{-1}$ to rates comparable with those in ecosystems with low $\mathrm{N}$ loads. Denitrification rates were therefore not necessarily lower than those in natural systems, but the efficiency by which $\mathrm{N}$ was removed, as $\mathrm{N}_{2}$ gas, was significantly lower (0.4 to $2 \%$ ).

The low denitrification efficiency is consistent with whole-farm, whole-season $\mathrm{N}$ budgets for shrimp farms, which showed that the difference between $\mathrm{N}$ inputs (feed $90 \%$, intake water $5 \%$, stock $5 \%$ ) and outputs (harvest $26 \%$, sediment $14 \%$, discharge water $57 \%$ ) was only $3 \%$ (Preston et al. 2000). This was assumed to be due to denitrification.

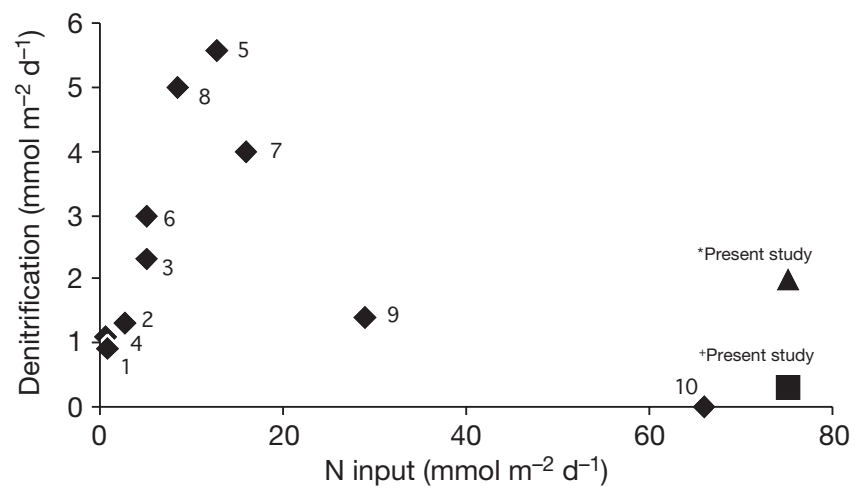

Fig. 5. Nitrogen $(\mathrm{N})$ input versus denitrification rates (mmol $\mathrm{m}^{-2} \mathrm{~d}^{-1}$ ) at various sites: ${ }^{1}$ Moreton Bay, Australia (acetylene block, slurry method, Dennison \& Abal 1999); ${ }^{2}$ Narragansett Bay, USA $i{ }^{3}$ Delaware Bay, USA $i{ }^{4}$ Baltic Sea; ${ }^{5}$ Tejo Estuary, Portugal $\left(\mathrm{N}_{2}\right.$ method except for Baltic Sea data where nitrate $\mathrm{NO}_{3}{ }^{-}$anomalies were used, Seitzinger 1988); ${ }^{6}$ Central Port Phillip Bay, Australia (benthic chamber method, Berelson et al. 1998) ${ }^{7}$ North Port Phillip Bay, Australia (benthic chamber method) ${ }_{i}{ }^{8}$ Norsminde Fjord, Denmark (acetylene block, intact cores method, Jørgensen \& Sørensen 1988); ${ }^{9}$ Fish ponds (acetylene block, intact cores method, Hall et al. 1992); ${ }^{10}$ Fish cages (acetylene block, in situ method). ${ }^{*}$ Present study — acetylene block method; ${ }^{+}$Present study — inferred benthic flux

Low denitrification efficiency has also been measured in fish ponds (Blackburn et al. 1988, Riise \& Roos 1997) and below fish cages (Kaspar et al. 1988, Hall et al. 1992, Christensen et al. 2000). These systems also have high organic $\mathrm{N}$ loadings to the sediment. It has been suggested that this is due to low rates of nitrification, and hence low $\mathrm{NO}_{3}{ }^{-}$availability for denitrification (Blackburn et al. 1988, Christensen et al. 2000).

The low denitrification efficiency in our study may be related to the availability of $\mathrm{NO}_{3}^{-}$and $\mathrm{NO}_{2}^{-}$. The $\mathrm{NO}_{3}{ }^{-}+\mathrm{NO}_{2}{ }^{-}$concentrations in the water column and sediment porewaters were relatively low compared with $\mathrm{NH}_{4}{ }^{+}$concentrations, and there were low $\mathrm{NO}_{3}{ }^{-}+\mathrm{NO}_{2}{ }^{-}$ fluxes into the sediment. This suggests that nitrification rates were low in this system. In the outer zone of our ponds, the organic supply to the sediment was low, but the $\mathrm{O}_{2}$ supply was high, creating a more suitable environment for nitrification and denitrification to proceed. The high organic supply rate and relatively low $\mathrm{O}_{2}$ supply in the pond center resulted in anoxic sediments that are likely to have inhibited nitrification and, hence, subsequently reduced denitrification.

A previous study of the sediments below fish cages found inhibition of nitrification compared with sediments a few tens of metres away. Nitrification can be inhibited by low $\mathrm{O}_{2}$ tension, and high hydrogen sulfide, unionized ammonia $\left(\mathrm{NH}_{3}\right)$ and $\mathrm{NO}_{2}{ }^{-}$concentrations, which in turn affects denitrification rates. These conditions frequently occur in intensive shrimp ponds 
(Suplee \& Cotner 1996, Cowan et al. 1999). It has been suggested that inhibition of nitrification by exposure to sulfide is the explanation for the link between organic loading and denitrification (Berelson et al. 1998). Alternatively or additionally, the flushing rates in the ponds (up to $10 \% \mathrm{~d}^{-1}$ ) may prevent slow-growing nitrifying bacteria from becoming established.

Benthic chambers provide an in situ method of measuring microbial processes and resulting nutrient fluxes in sediments. Previous studies in both shallow coastal and deep water sediments have shown that the rates obtained are a good representation of natural fluxes (Reay et al. 1995, Nicholson et al. 1999). In addition, mixing rates in the chambers and $\mathrm{O}_{2}$ levels were within the range of levels in shrimp ponds. Therefore, the nutrient diffusion rates and sediment $\mathrm{O}_{2}$ demand measured in our study are likely to be a reasonable representation of the flux rates in ponds.

To maintain adequate water quality in shrimp ponds and prevent the buildup of toxic $\mathrm{NH}_{3}$, it is common practice to discharge water intermittently into adjacent estuaries and rivers (Funge-Smith \& Briggs 1998, Preston et al. 2000). In addition to flushing high $\mathrm{NH}_{4}{ }^{+}$concentrations from ponds, unstable phytoplankton blooms can develop, which, if not flushed from the ponds, would die and create anoxic conditions on the sediment surface. The poor environmental performance of shrimp farming is due, in part, to the practice of discharging nutrient-rich discharge water into coastal areas. Our study has shown that sediment processes in shrimp ponds can contribute substantially to the nutrient discharge loads, particularly in the form of $\mathrm{NH}_{4}{ }^{+}$.

The shrimp farming industry is under increasing pressure from the public and environmental regulators to reduce nutrient loads discharged from farms and improve their sustainability (Naylor 1998, 2000). Reduction of $\mathrm{N}$ discharges from shrimp farms would be enhanced if microbial processes that remove $\mathrm{N}$ were promoted. However, this study has shown that one such process, denitrification, was not effective in reducing waste $\mathrm{N}$, and indeed $\mathrm{N}$ loading in the water column was exacerbated by ammonification of detrital $\mathrm{N}$. The removal of sludge from the ponds is likely to significantly reduce ammonification. However, further research on promoting microbial processes, such as stimulating nitrification and hence denitrification, and reducing feed wastage is needed to reduce waste nutrient loads from shrimp aquaculture.

Acknowledgements. Geoff Nicholson and Brett Abbott assisted with field sampling, Rob Cowdell and Daniel Wruck undertook nutrient analyses, Doug Capone and James Burns provided advice on acetylene block methods, Patricia Glibert and Erin Haramoto assisted with ${ }^{15} \mathrm{~N}$-nitrogen analyses, and Edward Butler, John Volkman, Peter Rothlisberg and 3 anonymous reviewers constructively criticized the manu- script. We acknowledge the support of the Marine and Freshwater Resources Institute, CSIRO Marine Research, the Cooperative Research Centre for Aquaculture, The University of Queensland, Moreton Bay Shrimp Farm, SeaFarm and Gold Coast Marine Aquaculture.

\section{LITERATURE CITED}

Bédard C, Knowles R (1989) Physiology, biochemistry and specific inhibitors of $\mathrm{CH}_{4}, \mathrm{NH}_{4}{ }^{+}$, and $\mathrm{CO}$ oxidation by methanotrophs and nitrifiers. Microbiol Rev 53:68-84

Berelson WM, Heggie D, Longmore A, Kilgore T, Nicholson G, Skyring G (1998) Benthic nutrient recycling in Port Phillip Bay, Australia. Estuar Coast Shelf Sci 46:917-934

Blackburn TH, Lund BA, Krom MD (1988) C- and N-mineralization in the sediments of earthern marine fishponds. Mar Ecol Prog Ser 44:221-227

Boucher G, Boucher-Rodoni R (1988) In situ measurement of respiratory metabolism and nitrogen fluxes at the interface of oyster beds. Mar Ecol Prog Ser 44:229-238

Briggs MRP, Funge-Smith SJ (1994) A nutrient budget of some intensive marine shrimp ponds in Thailand. Aquacult Fish Manage 5:89-811

Burford MA (1997) Phytoplankton dynamics in shrimp ponds. Aquacult Res 29:351-360

Burford MA, Glibert PM (1999) Short-term nitrogen uptake and regeneration in early and late growth phase shrimp ponds. Aquacult Res 30:215-227

Burford MA, Peterson EL, Baiano JCF, Preston NP (1998) Bacteria in shrimp pond sediments: their role in mineralizing nutrients and some suggested sampling strategies. Aquacult Res 29:843-849

Christensen PB, Rysgaard S, Sloth NP, Dalsgaard T, Schwærter S (2000) Sediment mineralization, nutrient fluxes, denitrification and dissimilatory nitrate reduction to ammonium in an estuarine fjord with sea cage trout farms. Aquat Microb Ecol 21:73-84

Cowan VJ, Lorenzen K, Funge-Smith SJ (1999) Impact of culture intensity and monsoon season on water quality in Thai commercial shrimp ponds. Aquacult Res 30:123-133

Dennison WC, Abal EG (1999) Moreton Bay Study: a scientific basis for the healthy waterways campaign. South East Queensland Regional Water Quality Management Strategy Team, Brisbane

Dickson AG, Goyet C (eds) (1996) Handbook of methods for the analysis of the various parameters of the carbon dioxide system in seawater, version 2.1. ORNL/CDIAC-74, Oak Ridge National Laboratory, TN

Funge-Smith SJ, Briggs MRP (1998) Nutrient budgets in intensive shrimp ponds: implications for sustainability. Aquaculture 164:117-133

Glibert PM, Lipschultz F, McCarthy JJ, Altabet MA (1982) Isotope dilution models of uptake and remineralization of ammonium by marine plankton. Limnol Oceanogr 27: $639-650$

Hall POJ, Holby O, Kollberg S, Samuelsson M-O (1992) Chemical fluxes and mass balances in a marine fish cage farm. IV. Nitrogen. Mar Ecol Prog Ser 89:81-91

Hargreaves JA (1998) Nitrogen biogeochemistry of aquaculture ponds. Aquaculture 166:181-212

Heggie DT, Skyring GW, Orchardo J, Longmore AR, Nicholson GJ, Berelson WM (1999) Denitrification and denitrifying efficiencies in sediments of Port Phillip Bay: direct determinations of biogenic $\mathrm{N}_{2}$ and $\mathrm{N}$-metabolite fluxes with implications for water quality. Mar Freshw Res 50: 589-596 
Jickells TD (1998) Nutrient biogeochemistry of the coastal zone. Science 281:217-222

Jørgensen BB (1996) Material flux in the sediment. In: Jørgensen BB, Richardson K (eds) Eutrophication in coastal marine ecosystems. Coastal and estuarine studies 52 . American Geophysical Union, Washington, p 115-135

Jørgensen KS, Sørensen J (1988) Two annual maxima of nitrate reduction and denitrification in estuarine sediment (Norsminde Fjord, Denmark). Mar Ecol Prog Ser 48: 147-154

Juliette LY, Hyman MR, Arp DJ (1993) Inhibition of ammonia oxidation in Nitromonas europaea by sulfur compounds: thioethers are oxidized to sulfoxides by ammonia monooxygenase. Appl Environ Microbiol 59:3718-3722

Karakassis I, Tsapakis M, Hatziyanni E (1998) Seasonal variability in sediment profiles beneath fish farm cages in the Mediterranean. Mar Ecol Prog Ser 162:243-252

Kaspar HF, Gillespie PA, Boyer IC, MacKenzie AL (1985) Effects of mussel aquaculture on the nitrogen cycle and benthic communities in Kenepuru Sound, Marlborough Sounds, New Zealand. Mar Biol 85:127-136

Kaspar HF, Hall GH, Holland AJ (1988) Effects of sea cage salmon farming on sediment nitrification and dissimilatory nitrate reductions. Aquaculture 70:333-344

Knowles R (1990) Acetylene inhibition techniques: development, advantages, and potential problems. In: Revsbech NP, Sørensen J (eds) Denitrification in soil and sediment. Plenum Press, New York, p 151-166

Martin JLM, Veran Y, Guelorget O, Pham D (1998) Shrimp rearing: stocking density, growth, impact on sediment, waste output and their relationships studied through the nitrogen budget in rearing ponds. Aquaculture 164: 135-149

Mazouni N, Gaertner J-C, Deslous-Paoli JM, Landrein S, d'Oedenberg MG (1996) Nutrient and oxygen exchange at the water-sediment interface in a shellfish farming lagoon (Thau, France). J Exp Mar Biol Ecol 205:91-113

McCaig AE, Phillips CJ, Stephen JR, Kowalchuk GA and 4 others (1999) Nitrogen cycling and community structure of proteobacterial $\beta$-subgroup ammonia-oxidizing bacteria within polluted marine fish farm sediments. Appl Environ Microbiol 65:213-220

Moriarty DJW (1986) Bacterial productivity in ponds used for culture of penaeid shrimps. Microb Ecol 12:259-269

Naylor RL, Goldburg RJ, Mooney H, Beveridge M and 6 others (1998) Nature's subsidies to shrimp and salmon farming. Science 282:883-884

Naylor RL, Goldburg RJ, Primavera JH, Kautsky N and 6 others (2000) Effect of aquaculture on world fish supplies. Nature 405:1017-1024

Nicholson GJ, Longmore AR, Berelson WM (1999) Nutrient fluxes measured by two types of benthic chamber. Mar Freshwat Res 50:567-572

Parsons TR, Maita Y, Lalli CM (1984) A manual of chemical and biological methods for seawater analysis. Pergamon Press, Oxford

Editorial responsibility: Otto Kinne (Editor), Oldendorf/Luhe, Germany
Peterson EL (1999) Benthic shear stress and sediment condition. Aquacult Eng 21:81-111

Phillips MJ, Kwei Lin C, Beveridge MCM (1993) Shrimp culture and the environment: lessons from the world's most rapidly expanding warmwater aquaculture sector. In: Pullin RSV, Rosenthal H, Maclean JL (eds) Environment and aquaculture in developing countries. ICLARM, Manila, p 171-196

Preston NP, Jackson CJ, Thompson P, Austin M, Burford MA (2000) Prawn farm effluent: composition, origin and treatment. Fisheries Research and Development Corporation final report, Project No. 95/162. FRDC, Canberra

Rahmatullah M, Boyde TRC (1980) Improvements in the determination of urea using diacetyl monoxime; methods with and without deproteinisation. Clin Chim Acta 107: 3-9

Reay WG, Gallagher DL, Simmons GM Jr (1995) Sedimentwater column and nutrient fluxes in nearshore environments of the Delmarva Peninsula, USA. Mar Ecol Prog Ser $118: 215-227$

Riise JC, Roos N (1997) Benthic metabolism and the effects of bioturbation in a fertilised polyculture fish pond in northeast Thailand. Aquaculture 150:45-62

Rosenberry B (2000) World shrimp farming 2000, No. 13. Shrimp News International, San Diego

Santschi P, Hohener P, Benoit G, Buchholtz-ten Brink M (1990) Chemical processes at the sediment-water interface. Mar Chem 30:269-315

Seitzinger SP (1988) Denitrification in freshwater and coastal marine ecosystems: ecological and geochemical significance. Limnol Oceanogr 33:702-724

Seitzinger SP, Nielsen LP, Caffrey J, Christensen PB (1993) Denitrification measurements in aquatic sediments: a comparison of three methods. Biogeochemistry 23: $147-167$

Sloth NP, Blackburn H, Hansen LS, Risgaard-Petersen N, Lomstein BA (1995) Nitrogen cycling in sediments with different organic loadings. Mar Ecol Prog Ser 116:163-170

Smith PT (1996) Physical and chemical characteristics of sediments from shrimp farms and mangrove habitats on the Clarence River, Australia. Aquaculture 146:47-83

Sornin JM, Collos Y, Delmas D, Feuillet-Girard M, Gouleau D (1990) Nitrogenous nutrient transfers in oyster ponds: role of sediment in deferred primary production. Mar Ecol Prog Ser 68:15-22

Suplee MW, Cotner JB (1996) Temporal changes in oxygen demand and bacterial sulfate reduction in inland shrimp ponds. Aquaculture 145:141-158

Technicon (1977) Individual/simultaneous determination of nitrogen or phosphorus in $\mathrm{BD}$ acid digests. Technicon Industrial Method No. 329-74 W/B. Technicon Industrial Systems, Tarrytown, p 10591

Udy J, Dennison WC (1997) Growth and physiological responses of three seagrass species to elevated sediment nutrients in Moreton Bay, Australia. J Exp Mar Biol Ecol 217:253-277

Submitted: September 12, 2000; Accepted: May 10, 2001 Proofs received from author(s): December 10, 2001 